Задорожна Наталія Тимофіївна, кандидат фізико-математичних наук, завідувач відділу, Інститут інформаційних технологій і засобів навчання НАПН України, м. Київ, e-mail: nzalert@ rambler.ru

Литвинова Світлана Григорівна, молодший науковий співробітник, Інститут інформаційних технологій і засобів навчання НАПН України, м. Київ, e-mail: s_litvinova@i.ua,

\title{
МЕТОДОЛОГІЯ СТВОРЕННЯ І КООРДИНУВАННЯ ВІРТУАЛЬНИХ ПРЕДМЕТНИХ СПІЛЬНОТ НА БАЗІ ВЕБ-ТЕХНОЛОГІЙ
}

\begin{abstract}
Анотація
Стаття присвячена аналізу віртуальних предметних спільнот i реалізації завдань, що включають розробку структури предметних спільнот, залучення вчителів-предметників до співпраці у спільнотах, створення інформаційнометодичних, дидактичних та розвивальних матеріалів, забезпечення умов їх використання у школі, підтримка діяльності спільноти за допомогою блогів.

У статті визначено поняття віртуальної предметної спільноти, іiї характерні особливості і види (стабільна, популярна, активна, база знань), описано структуру віртуальної предметної спільноти, здійснено аналіз за критеріями: учасники, методичне забезпечення, розробки уроків, презентації, фотоматеріали, відеоуроки, посилання, оголошення.

Ключові слова: віртуальні спільноти, віртуальні предметні спільноти, структура віртуальної спільноти, природничо-математична освіта, мережа, якість шкільної освіти, види спільнот, база знань.

Постановка проблеми. Розбудова віртуальних предметних спільнот, як інноваційний процес у загальній середній освіти, створила умови для підтримки діяльності вчителів-новаторів. В останні роки багато робиться для того, щоб використати досвід обміну знаннями і залучити вчителів-предметників до участі у предметних спільнотах, де в рамках окремої спільноти всі учасники можуть обмінюватися повідомленнями, текстовими документами, відео- й аудіофайлами, а
\end{abstract}


також знаннями, які вони можуть використати у своїй діяльності. Нові комунікаційні технології такі, як веб-технології, забезпечують можливість учителям співпрацювати 3 іншими вчителями, дізнаватися про нові ресурси і можливості впровадження їх у навчально-виховний процес i, як наслідок, сприяти підвищенню якості шкільної природничо-математичної освіти.

Державна цільова соціальна програма підвищення якості шкільної природничоматематичної освіти на період до 2015 року визначає фундаментальну природничоматематичну освіту однією з основних факторів розвитку особистості, яка потребує оновлення змісту природничо-математичної освіти з урахуванням суспільних запитів, потреб інноваційного розвитку науки і виробництва, запровадження сучасних методів навчання, поліпшення якості підготовки і видання навчально-методичної літератури, удосконалення механізмів оцінювання результатів навчальної діяльності тим, що визначено у Концепції Державної цільової соціальної програми підвищення якості шкільної природничо-математичної освіти на період до 2015 року [4]. Виходячи із завдань цієї Програми, було сформульовано завдання актуального дослідження щодо розроблення методології створення і координації віртуальних предметних спільнот. Це дослідження здійснюється в рамках науково-дослідної роботи «Методологія інформатизації наукової і управлінської діяльності установ НАПН України на основі веб-технологій» ДР№ 0112U000282 в Інституті інформаційних технологій і засобів навчання НАПН України. Завдання дослідження полягає в розробленні структури предметної спільноти, залученні вчителів-предметників до колаборації у спільноті, створенні інформаційно-методичних, дидактичних та розвивальних матеріалів 3 природничо-математичних предметів, забезпечення умови їх використання у школі, проведення аналізу діяльності спільнот. У статті представлено попередні результати цього дослідження.

Аналіз наукових досліджень. Наукові пошуки питання обумовлені широким використанням мережі Інтернет, як комунікаційного середовища 3 широким комунікаційним потенціалом. $\mathrm{y}$ зарубіжній науковій літературі дослідження віртуальних спільнот мають, в основному, описовий характер і зорієнтовані на розв’язання таких завдань: визначення структурних властивостей віртуальних спільнот (Фігалло К., Портер К., Джонс К., Кришнамерти С., Бленкард А., Харрісон С. та ін.), педагогічний підхід до вивчення віртуальних спільнот 
Патаракін Є. Д. Розвиток віртуальних спільнот розкрито у працях таких науковців, як: Биков В. Ю., Жалдак М. І., Задорожна Н. Т., Малицька І. Д., Морзе Н. В., Осадчий В. В. (Україна), Андрєєв О. О., Патаракін Є. Д., Полат Є. С., Хуторський А. В., Чураєва Н. С. (Росія).

У межах спільного проекту Національної академії педагогічних наук України і компанії «Майкрософт Україна» було створено український сегмент глобальної мережі «Партнерство в навчанні», де створено технологічні засоби підтримки діяльності спільнот з метою надання доступу до інформаційних ресурсів про новітні IКТ, забезпечення умов спільної роботи над розробкою уроків, навчальних i методичних матеріалів, обміну досвідом і ідеями щодо інноваційної діяльності вчителів з метою покращання якості навчання.

Використовуючи платформу мережі «Партнерство в навчанні» і враховуючи тенденції інноваційного розвитку ІКТ такі, як хмарні технології, веб-технології (сайти, портали, блоги), було започатковано віртуальні предметні спільноти вчителів математики, фізики, хімії, біології, географії, інформатики [2].

Хмарні технології, такі як SAAS, можуть бути використані в таких напрямах діяльності вчителів-предметників загальноосвітніх навчальних закладів: робота зі спільними документами (Google Docs, Web Apps), організація вебінарів, подорож до віртуальних музеїв, навчання у віртуальних класах, відвідування віртуальних бібліотек тощо. Проте за прогнозом експертів, з розвитком даного напрямку, до кінця 2016 року більше $50 \%$ найбільших світових компаній будуть зберігати важливу інформацію про своїх клієнтів і користувачів у «хмарних» сховищах, розміщених у системах зовнішніх провайдерів (тобто не на власних серверах). Дана тенденція буде обумовлена можливістю економії на IT-витратах (http://cbto.com.ua/it-prohnoz-do2016-r.html), що актуально саме для загальної середньої освіти.

Веб-технології зарекомендували себе серед освітян у вигляді тематичних сайтів, освітніх порталів (мереж) і спільнот.

Аналізуючи світові тенденції і практичне використання інновацій у питаннях веб-технологій, ми в дослідженні зупинилися на методології створення i координування віртуальних предметних спільнот і використання ii для спільнот природничо-математичних дисциплін. 
Метою статті є аналіз віртуальних предметних спільнот, представлення характерних особливостей i видів, подання результатів діяльності спільнот із природничо-математичних предметів.

Основний зміст матеріалу. Систематичне використання IКТ під час навчання предметів природничо-математичного циклу в загальноосвітніх навчальних закладах спонукає вчителів до постійного і систематичного створення власних презентацій до окремих тем уроків, тестів, пошуку відео- й аудіофрагментів дослідів тощо. Виникає проблема збереження навчальних матеріалів, їх оцінювання, обміну 3 колегами, використання під час атестації, конкурсів. Виникає потреба у створенні і розвитку динамічних віртуальних предметних спільнот.

Віртуальна предметна спільнота - це об’ єднання вчителів-предметників, що виростає з мережі, має спільні інтереси, прагнення та цілі, активно спілкується між собою як на професійні, так і на непрофесійні теми.

Характерні особливості віртуальної предметної спільноти:

- відсутність бар’ єрів комунікації як психологічних, так і географічних;

- інтерактивний характер взаємодії членів, які можуть ефективно обмінюватися корисною і цікавою інформацією;

- можливість самопрезентації і самореалізації вчителів-предметників;

- неформальна структура он-лайн спілкування;

- структурований банк навчально-методичних матеріалів.

Види віртуальних предметних спільнот:

- стабільна: спільнота 3 періодичним наповнюванням навчальнометодичними матеріалами без надміру активних членів спільноти;

- популярна: спільнота із систематичним наповнюванням навчальнометодичними матеріалами і збільшенням кількості активних членів спільноти шляхом високої популярності;

- активна: спільнота-форум, метою якої є отримання відгуків чи реакції на ту чи іншу подію або отримання миттєвої консультації 3 нагальних питань діяльності вчителя-предметника;

- база знань: у сховищах спільноти накопичується якісна інформація 3 певного предмету. 
Особливості формування віртуальних предметних спільнот у мережі «Партнерство у навчанні»:

- $\quad$ відсутність відомостей про події, які відбуваються в предметній спільноті у момент, коли вчитель-предметник не в он-лайні;

- нечітке структурування навчальних і методичних матеріалів у віртуальних сховищах спільноти;

- відсутність єдиного принципу маркування документів;

- режиму чату, що унеможливлює живе спілкування або дискусію між учасниками спільноти.

Координація спільноти, ऑiі «повсякденне життя» підтримується на конференціях, семінарах, тренінгах за допомогою залучення нових учасників, мотивації дійсних учасників, використання матеріалів учасників під час атестації, обміну досвідом і т. д.

Структура віртуальної предметної спільноти (рис. 1) містить основні компоненти: учасників, спільні документи, посилання, оголошення, дискусії, події.

Інноваційний розвиток забезпечується мережею «Партнерство у навчанні», яка підтримує мотивацію вчителів-предметників використовувати IКТ у педагогічній діяльності методично, за допомогою вебінарів, конкурсів.

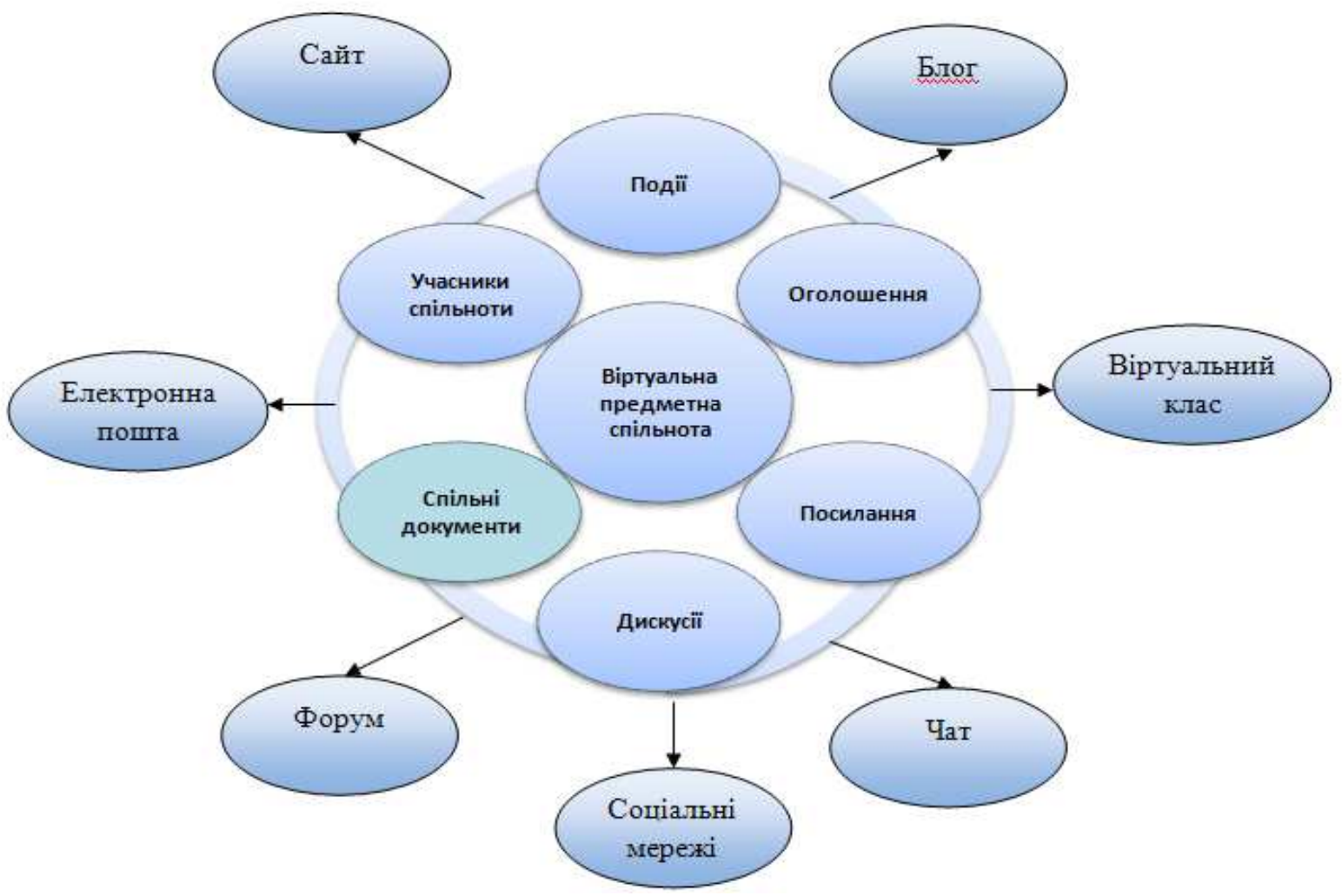


Рис. 1. Структура віртуальної предметної спільноти

Спільні документи - це документи які забезпечують педагогічну діяльність вчителя. Їх призначення: обмін, спільне використання, рецензування, обговорення, оцінювання, презентування тощо (рис. 2).

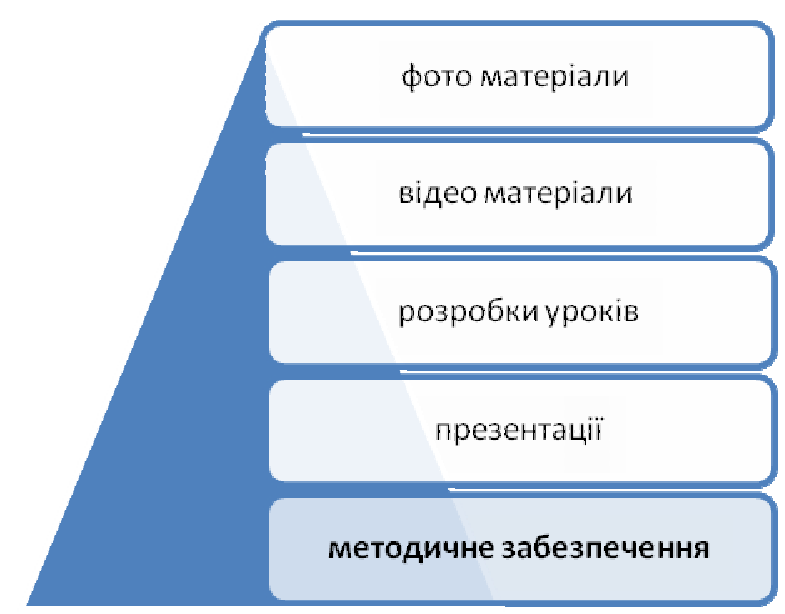

Рис. 2. Структура спільних документів

Аналіз діяльності віртуальної предметної спільноти здійснювався за такими критеріями: учасники (кількість), методичне забезпечення (кількість, види матеріалів), розробки уроків (кількість, відповідність стандартам), презентації (кількість, відповідність стандартам), фото (кількість, тематика), відео (кількість, тематика), посилання (кількість, тематика), оголошення (кількість, тематика).

Учасниками спільноти можуть бути як учителі, заступники директорів, так i методисти районних і обласних центрів. Про учасника спільноти можна дізнатися, в якому місті і школі він працює, переглянути його фото за потреби, зв'язатися з ним електронною поштою, переглянути його матеріали, залишити для нього повідомлення.

Специфіка мережі «Партнерство у навчанні» така, що відсутній чат і форум, що окреслює проблему колаборації, яку можна доповнити проведенням вебінарів або практичних семінарів у віртуальних класах [1].

Розгорнуте спілкування у блогах дає можливість провести круглий стіл, на якому всі учасники спільноти можуть висловити свою власну думку і занотувати іï для подальших врахувань у роботі. Координацію такого заходу бере на себе 
організатор круглого столу (блогер або координатор спільноти), який і вирішує, які саме дописи залишити для загалу, а які можна знищити.

Спільнота розростається не поступово, а хвилеподібно (рис. 3). Це залежить від:

- популяризації спільноти;

- навчальних тренінгів;

- методичних семінарів;

- електронного розсилання;

- залучення до спільноти під тематичні конкурси;

- періодичності проведення вебінарів тощо.

Розглянемо темпи розростання спільнот: "Інформатика" - 62 учасники, "Математика" - 56 учасників, "Хімія" - 40 учасників, “Фізика" - 37 учасників, “Біологія" - 36 учасників, “Географія" - 33 учасники (рис. 3).

Найактивнішими виявилися вчителі інформатики, вони легко оперують такими новими технологіями, як Інтернет, орієнтуються у функціонуванні веб-застосунків, миттєво реагують на системні зауваження і збої. Учителі математики менш обізнані в новітніх технологіях, але за статистикою більшість 3 них суміщає викладання предметів інформатика і математика. Далі спостерігаємо вчителів фізики, для яких спільнота - це віртуальне сховище для збереження відео з лабораторними роботами, природними явищами, науковими дослідженнями, моделями та інтерактивними наочностями.

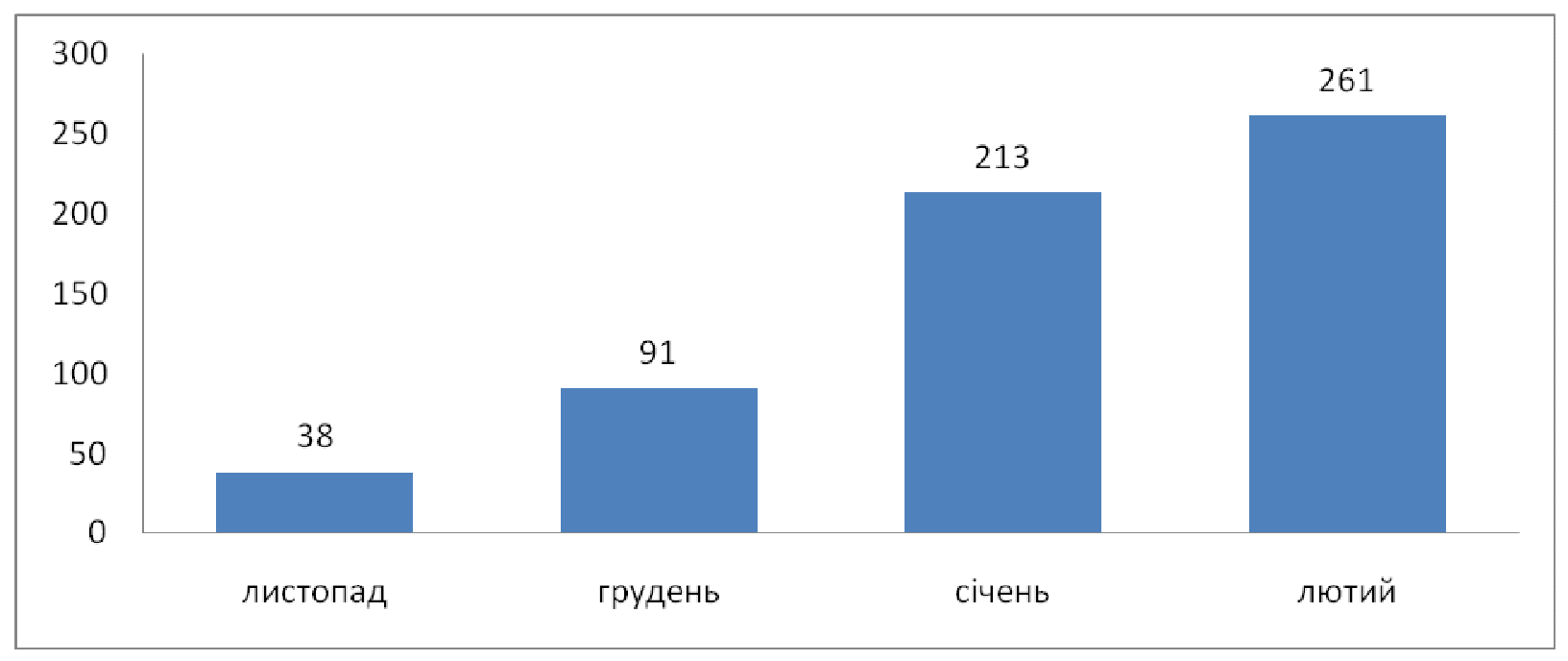

Рис. 3. Загальна кількість учасників у природничо-математичних спільнотах 
Методичне забезпечення. Усередині спільноти обмін знаннями і досвідом здійснюється у вигляді обміну професійними даними і відомостями - це нормативні і методичні матеріали для продуктивної роботи вчителя. Вони у будь-яку хвилину і будь-якому місці «під рукою» (рис. 4).

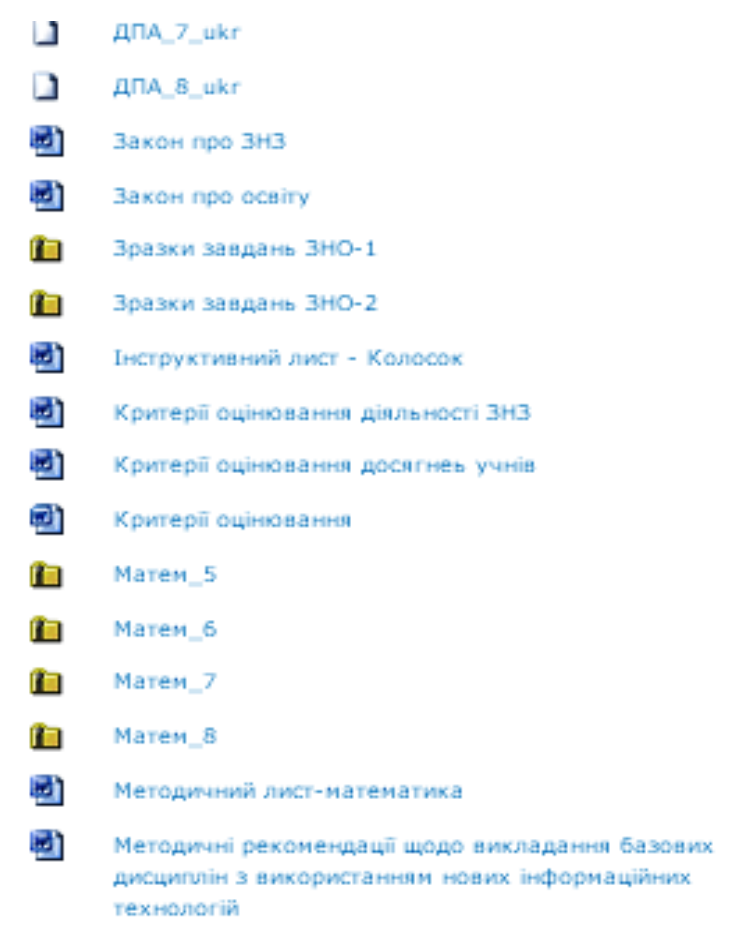

Рис. 4. Відображення документів у папках природничо-математичних спільнот

Наповнюваність сховищ методичними матеріалами залежить від:

- роботи координатора;

- методиста;

- наявності нормативно-методичної інформації на державних сайтах;

- зацікавлених осіб (директор, методист, ЦІППО, МОНмолодьспорт України);

- систематика виходу наказів, розпоряджень, листів тощо.

Розглянемо темпи заповнення віртуальних сховищ методичними матеріалами: “Інформатика” - 68 шт., “Фізика” - 20 шт., "Хімія” - 18 шт., "Математика” - 16 шт., “Біологія" - 14 шт., "Географія" - 13 шт.

Учителі фізики і хімії оперують значною кількість нормативних і методичних матеріалів. Це обумовлено необхідністю забезпечення безпеки діяльності учнів під час проведення дослідів, наявності різноманітних інструкцій щодо методики використання різноманітних приладів та ін. (рис. 5). 
Розробки уроків. Наповнюваність сховищ конспектами уроків залежить від:

- мотивації;

- вимог адміністрації навчального закладу;

- бажання вчителя;

- самоорганізації.

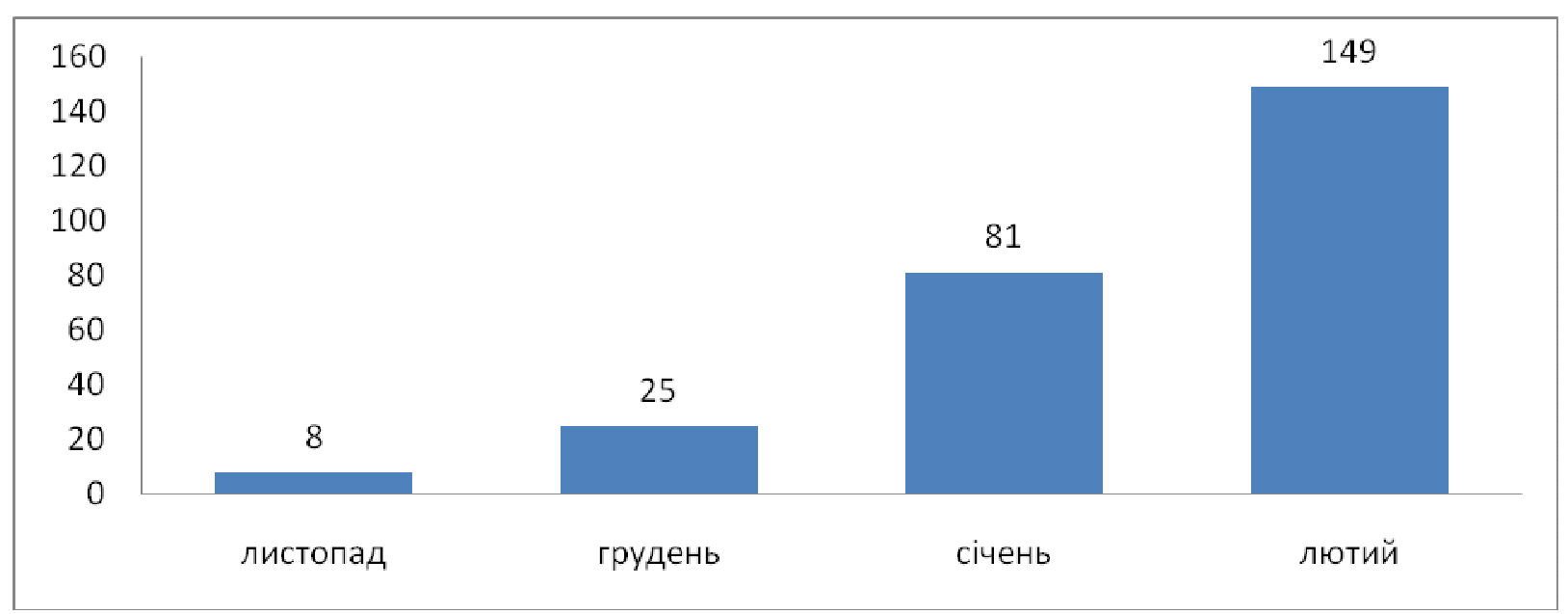

Рис. 5. Загальна кількість методичних і нормативних матеріалів у природничоматематичних спільнотах

Заповнення сховищ віртуальних предметних спільнот розробками уроків вчителів-предметників складає тільки $4 \%$ від кількості розміщених презентацій (рис. 5). Можна стверджувати, що «електронний конспект» учителя - ще й досі залишається на початковому рівні як створення, так і використання (рис. 6).

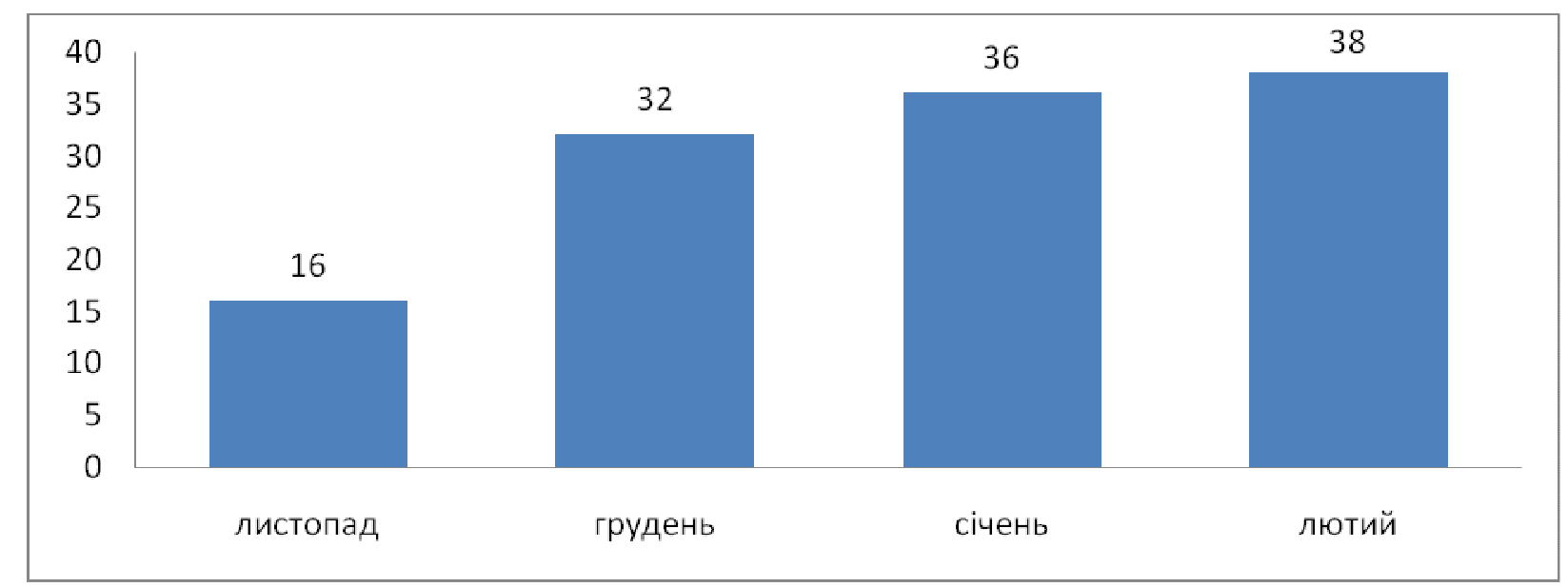

Рис. 6. Загальна кількість розробок електронних конспектів уроків у природничо-математичних спільнотах 
Презентаџіï уроків. Це самий доступний і популярний серед учителів вид матеріалів (рис. 7).

Учителі-предметники із задоволенням розроблюють презентації до уроків. Це обумовлено простотою використання під час уроку, можливістю збереження структури і плану уроку, можливістю включення кросвордів, цікавих логічних задач тощо.

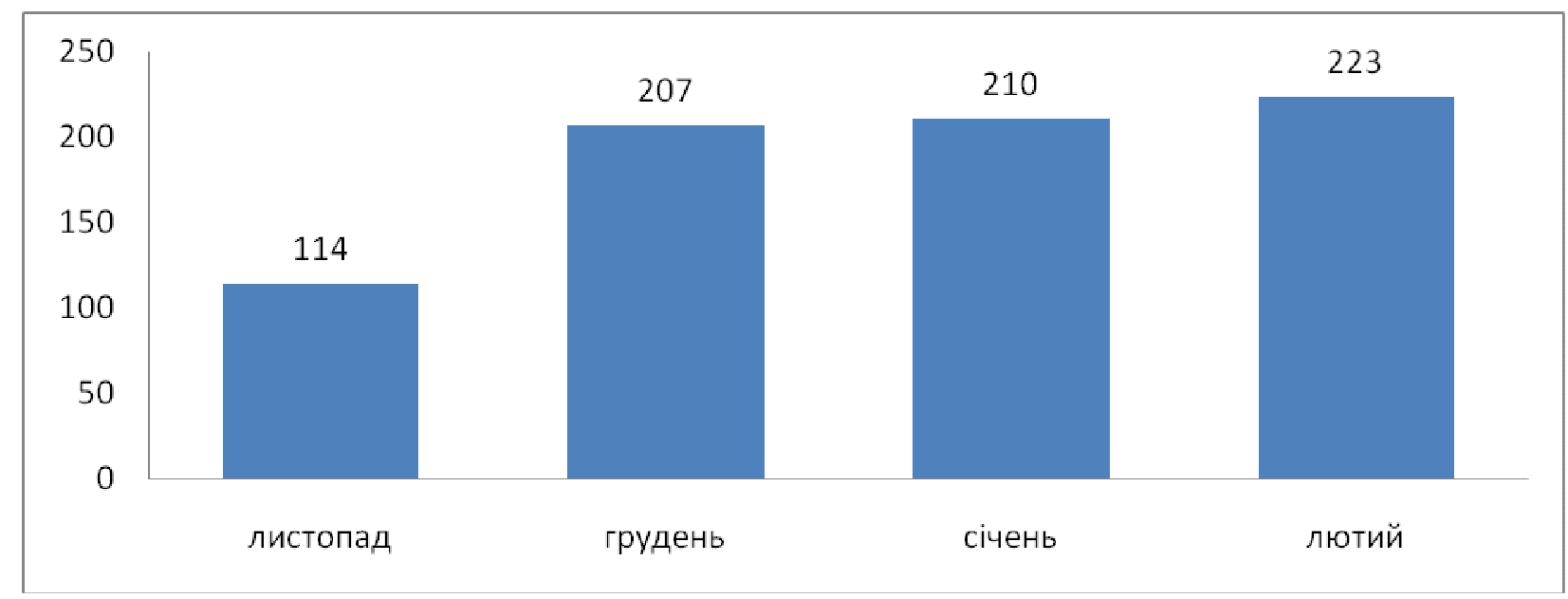

Рис. 7. Загальна кількість презентацій у природничо-математичних спільнотах

Відеоуроки. Вони відносяться до того типу матеріалів, якими обмінюються.

Наповнюваність сховищ методичними матеріалами залежить від:

- здатності вчителя зняти відеоролик;

- наявності навчального відео в мережі Інтернет;

- рівня організації роботи з учнями (батьками);

- наявності відеоуроків на електронних носіях тощо.

Розглянемо темпи заповнення віртуальних сховищ відеоуроками: “Хімія" 127 шт., “Фізика” - 95 шт., “Біологія” - 37 шт., “Інформатика” - 36 шт., "Географія” 27 шт., "Математика" - 5 шт.

Учителі математики практично не використовують відео на уроках. Це обумовлено складністю унаочнення предмету, відсутністю креативних ідей тощо (рис. 8). 


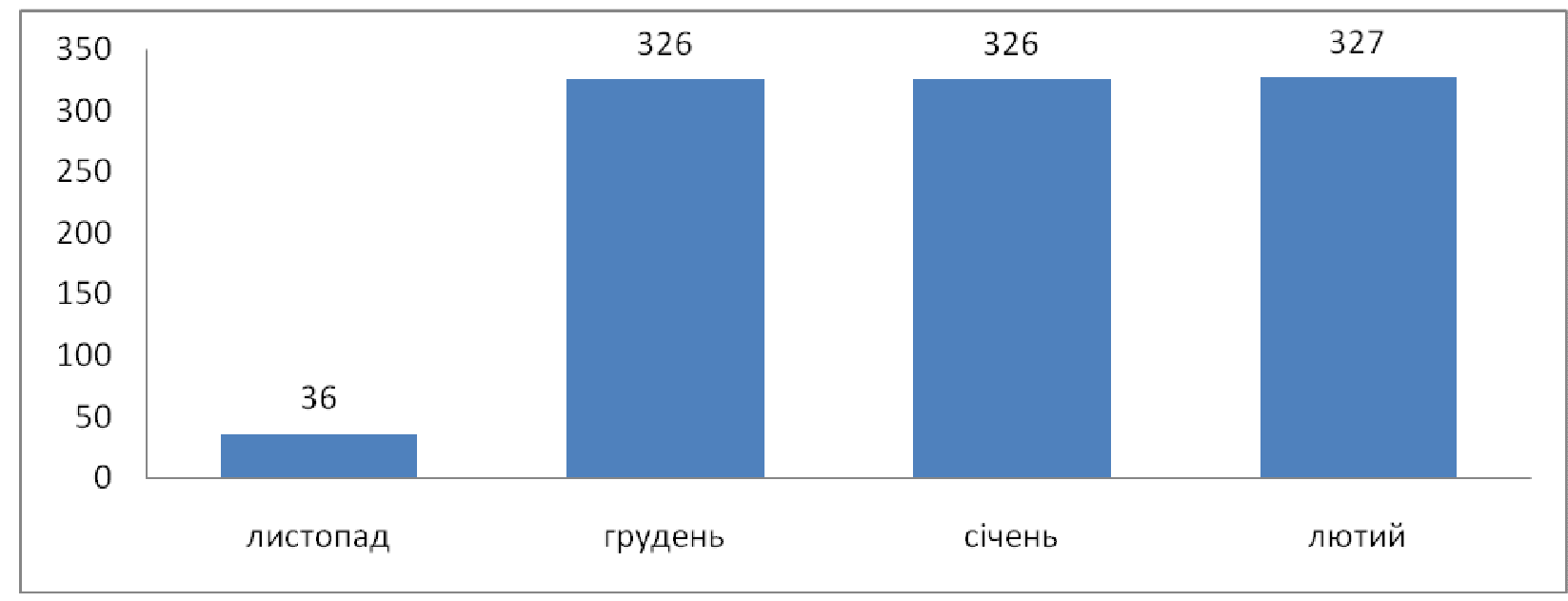

Рис. 8. Загальна кількість презентацій у природничо-математичних спільнотах

Фотоматеріали. Використовуються вчителями в презентаціях - фото вчених, явищ, видів будівель, фотоальбоми рослин, тварин тощо (рис. 9). Активність вчителів у наповненні сховищ фотоматеріалами низька й обумовлена відсутністю потреби вчителів (без них можна обійтися).

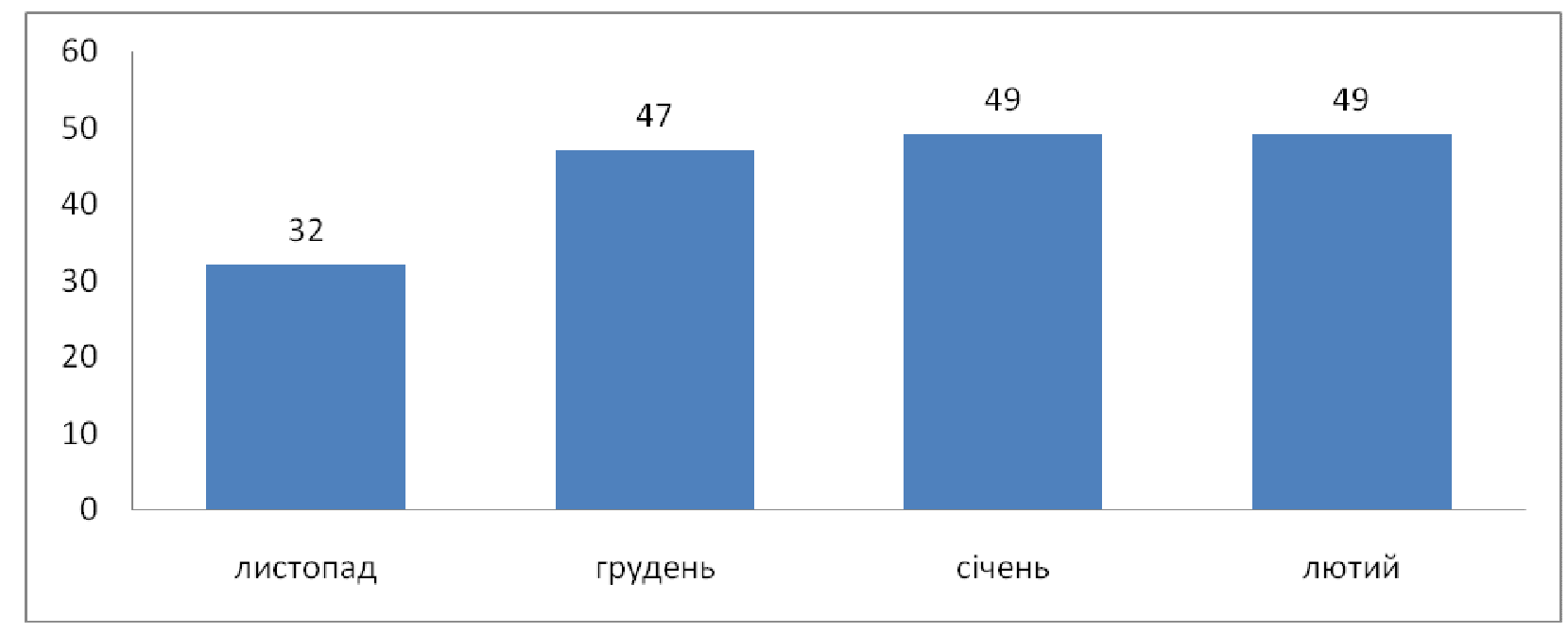

Рис. 9. Загальна кількість фотоматеріалів у природничо-математичних спільнотах

Оголошення. Їх розміщують за потреби спільноти (координатора) (рис. 10). 


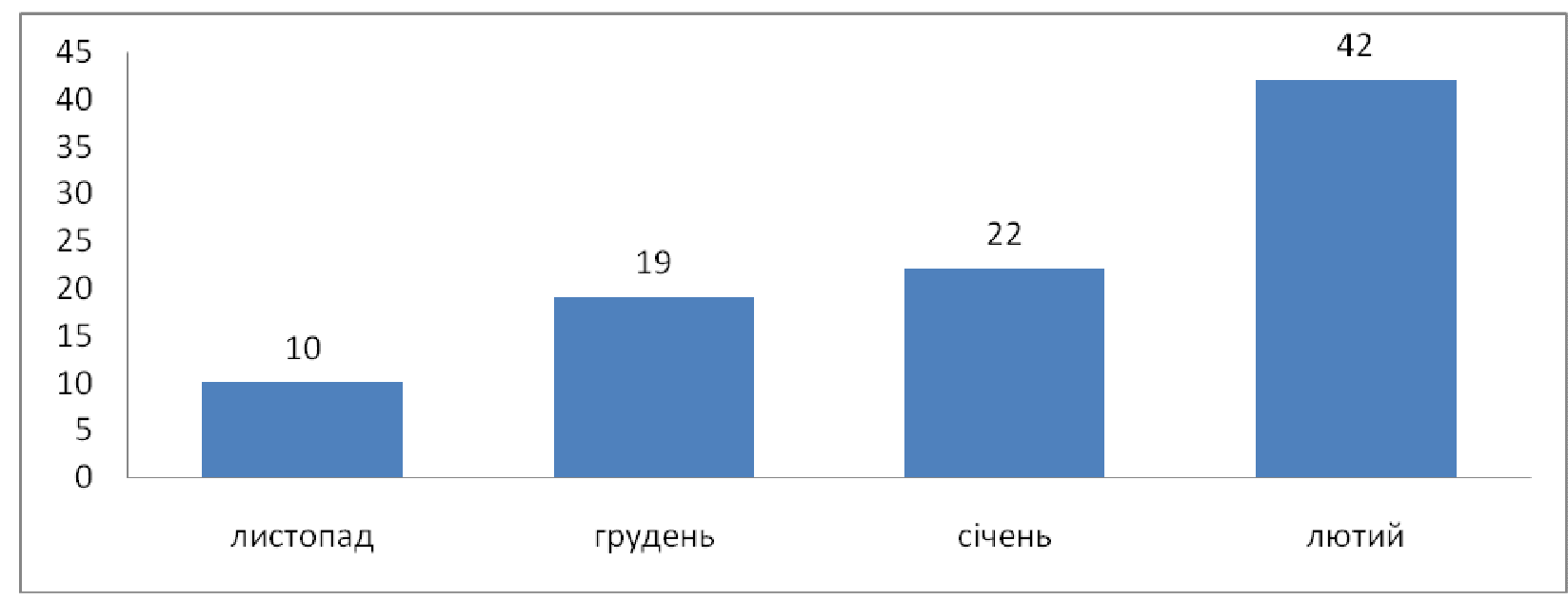

Рис. 10. Загальна кількість оголошень у природничо-математичних спільнотах

Як зазначалося раніше, для інтерактивної взаємодії вчителів-предметників, підсилення методичної спрямованості й підвищення компетентності можна використовувати блоги.

Блог (англ. blog, від web log - інтернет-журнал подій, інтернет-щоденник, онлайн-щоденник) - веб-сайт, основний вміст якого - регулярно додаються записи (пости), що містять текст, зображення або мультимедія.

Для блогів характерні недовгі записи часової значимості, відсортовані у зворотному хронологічному порядку (останній запис зверху).

Відмінності блогу від традиційного щоденника обумовлюються середовищем: блоги, зазвичай, публічні і передбачають сторонніх читачів, які можуть вступити в публічну полеміку з автором (у коментарі до блогозапису або своїх блогах).

Людей, які ведуть блог, називають блогерами - це я. Сукупність усіх блогів Мережі прийнято називати блогосферою.

Для блогів характерна можливість публікації відгуків (коментарів, «комментов») відвідувачами. Вона робить блоги середовищем мережевого спілкування, що має низку переваг перед електронною поштою, групами новин, вебфорумами і чатами. 

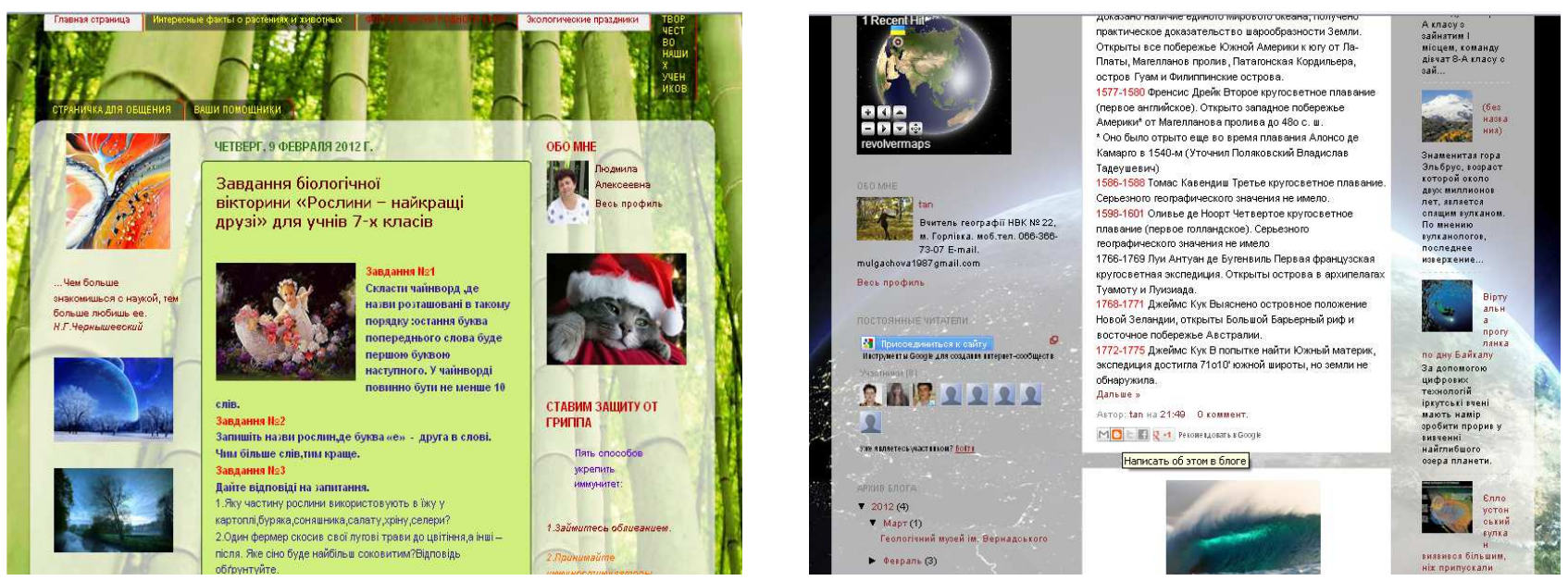

Рис. 11. Блог учителя біології http://sosian33.blogspot.com/

Рис. 12. Блог учителя фізики http://mulgachova.blogspot.com/
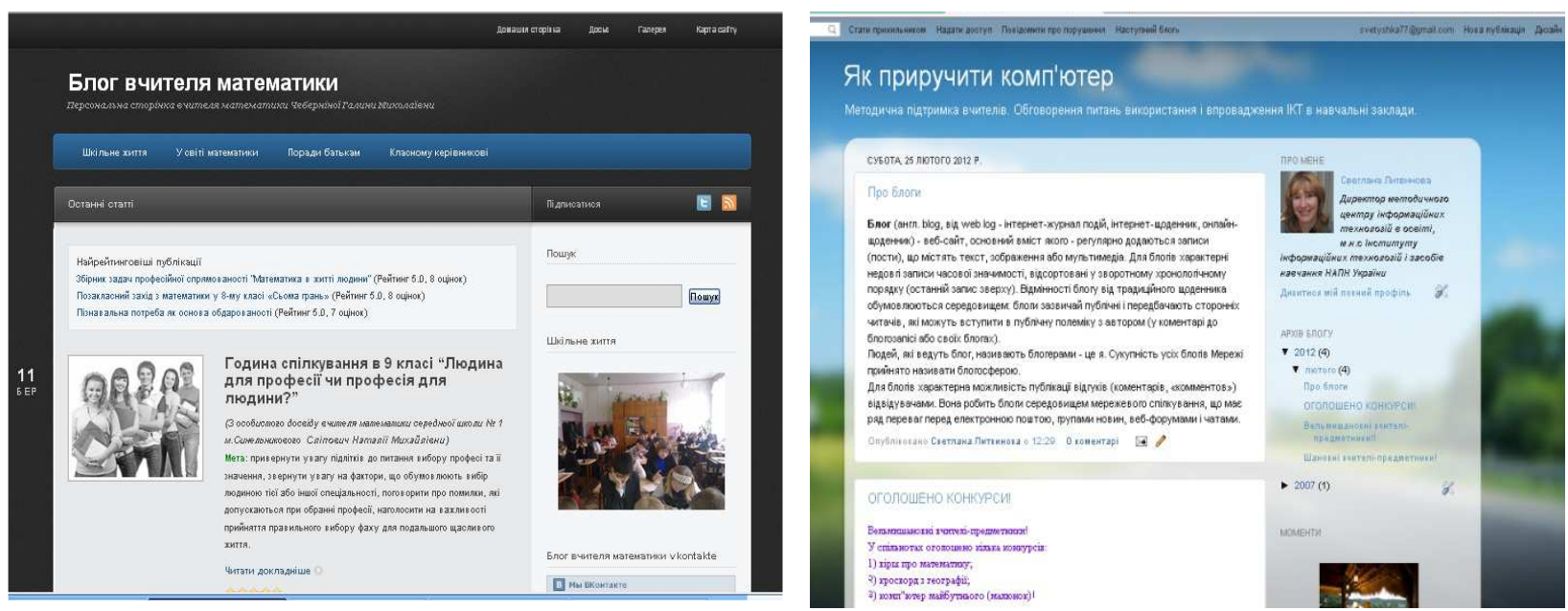

Рис. 13. Блог учителя математики http://math-teacher.org.ual

Рис. 14. Блог координатора віртуальної спільноти http://svebra.blogspot.com

Роль координатора спільноти: методична робота, спілкування вчителів, використання сховищ спільноти, супровід блогу тощо.

Методика використання віртуальних предметних спільнот реалізована у електронних матеріалах (презентація): «Про віртуальну предметну спільноту» (рис. 15) і «Методика використання віртуальної предметної спільноти» (рис. 16). 
Microsoft

Пошук в Мережі партнерстьо в навчанні

Партнерство в навчанні

\section{Головна Мійблокнот Учасники Спільноти Ресурси}

\begin{tabular}{|c|c|c|c|c|}
\hline$\square$ & Тип & Im'r & Змінено & Ким змінено \\
\hline & [1] & ТЯжінНЯ & 02.01.2012 8:24 & Svetlana Litvinova \\
\hline & (t) & чорна діра & $02,01.20128: 24$ & Svetlana Litvinova \\
\hline
\end{tabular}

Рис. 15. Зразок слайду презентації «Про віртуальну предметну спільноту»

\section{Спільні документи}

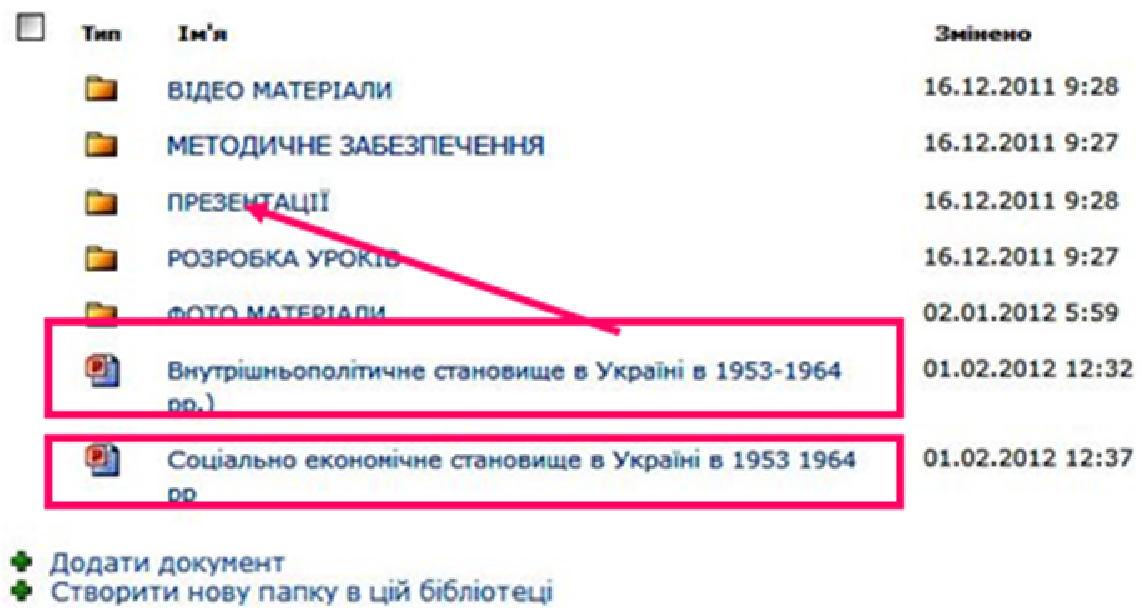

Рис. 16. Зразок слайду презентації «Методика використання віртуальної предметної спільноти»

\section{Висновки}

1. Віртуальні предметні спільноти - нове явище в педагогічній практиці. Виявлено необхідність створення професійних віртуальних спільнот учителівпредметників, спільно працювати над розробкою уроків, навчальними і методичними матеріалами, обмінюватися досвідом, ідеями.

2. Особливостями віртуальних предметних спільнот $\epsilon$ їх відкритість, доступність, простота використання та наявність необмежених віртуальних сховищ.

3. На активність i функціонування віртуальних предметних спільнот впливають потреба педагогів у спільноті, вибір платформи (порталу), наявність 
основного функціоналу, масовий характер, швидкість обміну документами, наявність зв’язків між учасниками, наявність віртуальних сховищ, проведення навчальних семінарів, тренінгів, підтримка учительських сайтів, блогів тощо.

Перспективи розвитку. Подальший розвиток представленої проблеми полягає у дослідження розвитку віртуальних предметних спільнот, моніторингу та координації спільнот з інформатики, фізики, хімії, математики, біології, географії у Мережі «Партнерство в навчанні».

\section{Список використаних джерел}

1. Литвинова С. Г. Віртуальний клас як комп'ютерно орієнтоване навчальне середовище вчителя загальноосвітнього навчального закладу [Електронний ресурс] / Світлана Григорівна Литвинова // Інформаційні технології і засоби навчання. - 2011.

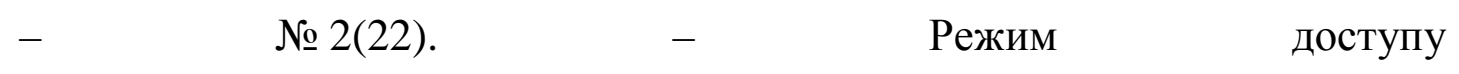

http://journal.iitta.gov.ua/index.php/itlt/article/view/331/387. - Назва з екрана.

2. Литвинова С. Г. Віртуальні предметні спільноти / Світлана Григорівна Литвинова // Інформаційно-комунікаційні технології в освіті: досвід, інновації, технічне забезпечення : збірник матеріалів Всеукраїнської наук.-практ. конф. (1-2 березня 2012 року, м. Суми). - Суми : РВВ СОІППО, 2012. - С. 39-42.

3. Патаракин Е. Д. Сетевые сообщества и обучение / Е. Д. Патаракин / - М. : «ПЕР СЭ», 2006 . - 112 c.

4. Про схвалення Концепції Державної цільової соціальної програми підвищення якості шкільної природничо-математичної освіти на період до 2015 року [Електронний ресурс]. - Режим доступу : http://zakon.rada.gov.ua/cgibin/laws/main.cgi?nreg=1720-2010-\%F0 - Заголовок з екрана.

\section{МЕТОДОЛОГИЯ СОЗДАНИЯ И КООРДИНАЦИИ ВИРТУАЛЬНЫХ ПРЕДМЕТНЫХ СООБЩЕСТВ НА БАЗЕ ВЕБ-ТЕХНОЛОГИЙ}

Задорожная Наталья Тимофеевна, кандидат физико-математических наук, заведующая отделом электронных информационных ресурсов и сетевых технологий, Институт информационных технологий и средств обучения НАПН Украины, г. Киев, e-mail: nzalert@ rambler.ru 
Литвинова Светлана Григорьевна, младший научный сотрудник, Институт информационных технологий и средств обучения НАПН Украины, г. Киев, e-mail: s_litvinova@i.ua

\section{Аннотация}

Статья посвящена анализу виртуальных предметных сообществ и реализации задач, включающих разработку структуры предметных сообществ, привлечение учителей-предметников к сотрудничеству в сообществах, создание информационнометодических, дидактических и развивающих материалов, обеспечению их использования в школе, поддержке деятельности сообщества посредством блогов.

В статье определено понятие виртуального предметного сообщества, его характерные особенности и виды (стабильное, популярное, активное, база знаний), описана структура виртуального предметного сообщества, осуществлен анализ по критериям: участники, методическое обеспечение, разработки уроков, презентации, фото материалы, видео урок, ссылки, объявления.

Ключевые слова: виртуальное сообщество, виртуальные предметные сообщества, структура виртуального сообщества, естественно-математическое образование, сеть, качество школьного образования, виды сообществ, база знаний.

\section{METODOLOGY TO CREATE AND COORDINATE THE VITRUAL SUBJECT COMMUNITIES BAZED ON WEB TECHNOLOGY}

Natalia T. Zadorozhna, PhD (physics and mathematics sciences), head of the Department of electronic informative resources and network technologies of the Institute of Information Technologies and Learning Tools of NAPS of Ukraine, Kyiv, e-mail: nzalert@ rambler.ru Svitlana G. Lytvynova, junior researcher of the Institute of Information Technologies and Learning Tools of NAPS of Ukraine, Kyiv, e-mail: s_litvinova@i.ua

\section{Resume}

The article analyzes the virtual subject communities and subject communities framework development. It describes how to encourage subject teachers to work in the community, to create awareness and learning, teaching and developing materials to ensure their use in schools, to support community through blogs.

There is a definition of the virtual subject community, its characteristics and types of (a stable, popular, active, knowledge base) in the article. The structure of the virtual subject 
community is given. There is the analysis of the community according to various criteria (participants, methodological support, developed lessons, presentations, photo files, video tutorial links and announcement).

Keywords: virtual community, virtual subject community, virtual community structure, math and science education, network, school education quality, communities types, knowledge base.

Матеріал надійшов до редакції 09.04.2012 p 